\title{
Erratum to: Complete chloroplast genome sequence of MD-2 pineapple and its comparative analysis among nine other plants from the subclass Commelinidae
}

RM Redwan ${ }^{1}$, A. Saidin ${ }^{2}$ and SV Kumar ${ }^{1 *}$

\section{Erratum}

After the publication of this work [1], we noticed that an incorrect version of Fig. 2 (Fig. 1 here) was published. The correct version of Fig. 2 has been corrected in the original article and is also included correctly below. The publisher apologizes for any inconvenience caused.

\footnotetext{
* Correspondence: vijay@ums.edu.my

${ }^{1}$ Biotechnology Research Institute, Universiti Malaysia Sabah, Jalan UMS

88400 Kota Kinabalu, Sabah, Malaysia

Full list of author information is available at the end of the article
} 


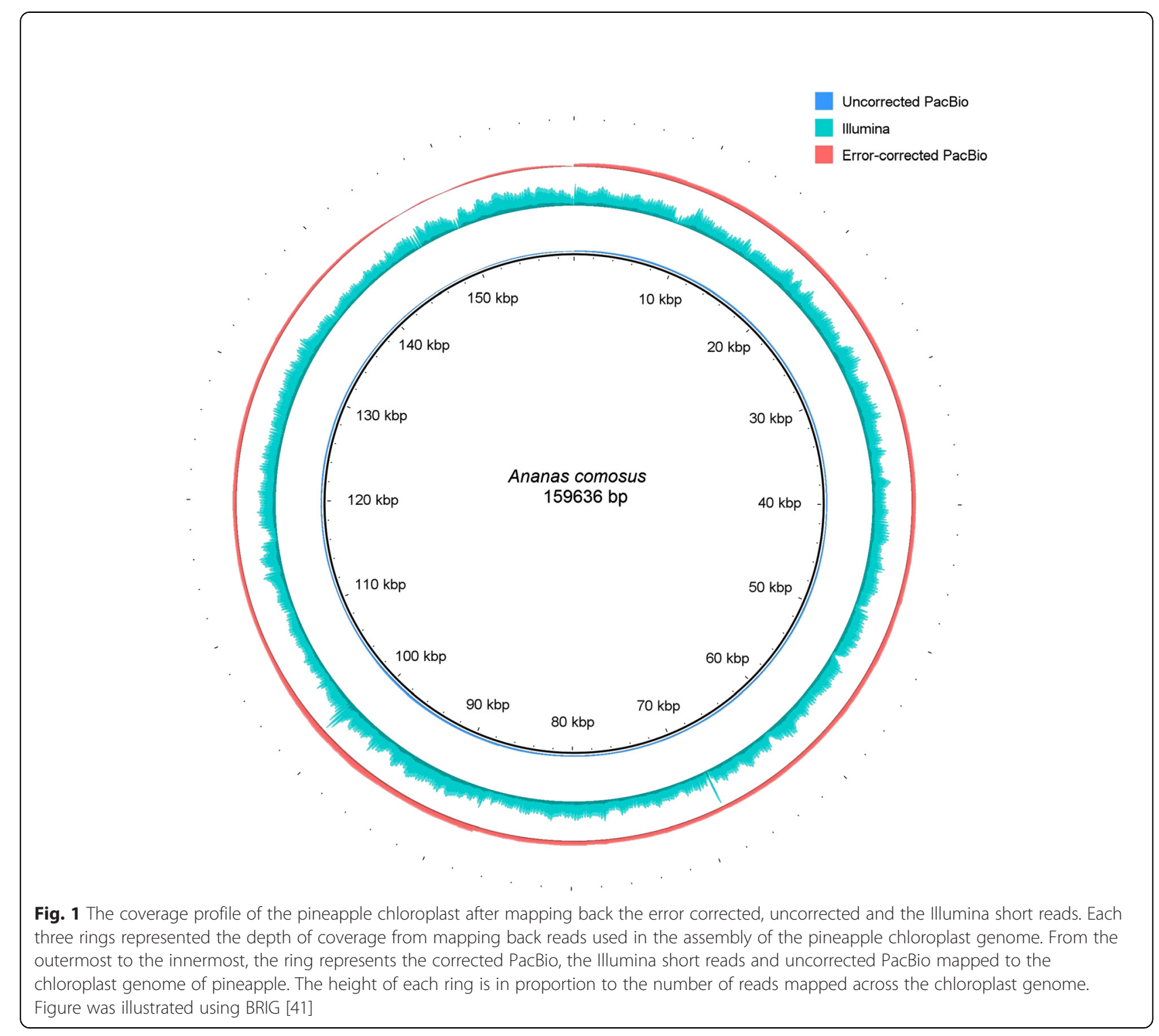


Author details

${ }^{1}$ Biotechnology Research Institute, Universiti Malaysia Sabah, Jalan UMS,

88400 Kota Kinabalu, Sabah, Malaysia. ${ }^{2}$ Novocraft Technology Sdn. Bhd, Two

Square, Seksyen 19, Petaling Jaya, Selangor, Malaysia.

Received: 21 September 2015 Accepted: 21 September 2015

Published online: 18 December 2015

\section{Reference}

1. Redwan RM et al. Complete chloroplast genome sequence of MD-2

pineapple and its comparative analysis among nine other plants from the subclass Commelinidae. J Plant Biol. 2015;15:196.

\section{Submit your next manuscript to BioMed Central} and take full advantage of:

- Convenient online submission

- Thorough peer review

- No space constraints or color figure charges

- Immediate publication on acceptance

- Inclusion in PubMed, CAS, Scopus and Google Scholar

- Research which is freely available for redistribution 